\title{
POLA ASUH DIALOGIS DAN METODE INDIVIDUAL DALAM PENDIDIKAN SEKS ISLAM PADA PENDIDIKAN AGAMA TERHADAP SIKAP ANAK BERBUSANA SESUAI DENGAN JENIS KELAMINNYA
}

\author{
Siti Muhayati*
}

\begin{abstract}
Abstrak
Pola Asuh Dialogis adalah pola asuh dimana orang tua memberi bimbingan, membina, mengamati, mengingatkan, memberi contoh dan mengajak dialog anak mengenai masalah yang dihadapi anak. Keterbatasan kemampuan orang tua maka anak dikirim ke sekolah untuk mengembangkan dan memperkuat jenis kelamin yang dibawa sejak dari rumah atau sejak lahir. Pendidikan Seks (berbusana sesuai jenis kelaminnya) merupakan ketrampilan maka untuk mengasuh anak agar bersikap berbusana sesuai jenis kelaminnya dengan metode individualisasi. Hasil peneitian menunjukkan bahwa pola asuh dialogis berpengaruh positif terhadap sikap anak berbusana sesuai jenis kelaminnya ( $\mathrm{Fo}>\mathrm{Ft}$ atau 38,55>4,11), metode individualisasi berpengaruh positif terhadap sikap anak berbusana sesuai jenis kelaminnya $(\mathrm{Fo}>\mathrm{Ft}$ atau 33,33>4.11), pola asuh dialogis dan metode individualisasi berpengaru positif terhadap sikap anak berbusana sesuai jenis kelaminnya $(\mathrm{Fo}>\mathrm{Ft}$ atau 6.32>4.11)
\end{abstract}

Kata kunci: Pola Asuh Dialogis, Metode Individual, Pendidikan Seks Islam, Berbusana Sesuai Dengan Jenis Kelaminnya

* Siti Muhayati adalah Dosen Program Studi Bimbingan dan Konseling Fakultas Ilmu Pendidikan IKIP PGRI Madiun 
Pendahuluan

Pola asuh adalah pendidikan dalam keluarga. Diantara pola asuh ada pola asuh dialogis. Pola asuh dialogis yaitu pola asuh orang tua dimana orang tua memelihara, mengasuh, membina, mendidik dan mengembangkan fithrah(potensi) anak dari waktu ke waktu sesuai dengan fithrah penciptaan manusia sebagai hamba Allah dan kholifah fil ard. Dalam pola asuh ini, orang tua membimbing, mengamati dan mengingatkan anak, memberi contoh dan menjawab pertanyaan anak dengan jawaban yang sesuai dengan usianya. Akibat pola asuh ini terhadap anak ialah anak akan selalu percaya diri, mandiri, hidupnya berarti, dan menjauhi segala keburukan bukan karena orang tua, tetapi karena dia merasakan akibat keburukan tersebut (Ummu Dini:2004).

Pengetrapan pola asuh dialogis ini dalam pembentukan sikap anak berbusana sesuai jenis kelaminnya yaitu dimana orang tua mengajari anak untuk berbusana sesuai jenis kelaminnya, selain itu orang tua memberi contoh pada anaknya bahwa ibu selalu memakai pakaian sesuai jenis kelaminnya yang menunjukan feminimitas sedang ayah memakai pakaian yang sesuai dengan jenis kelaminnya yang menunjukan maskulinnya, baik ada anak atau tidak anak didepan mereka, mereka tetap berbusana sesuai jenis kelaminnya, karena orang tua sebgai figur pertama dan utama dalam membentuk sikap anak berbusana sesuai jenis kelaminnya. Tinggi rendahnya sikap anak berbusana sesuai jenis kelaminnya tergantung 
pada tinggi rendahnya orang tua berbusana sesuai jenis kelaminnya. Sebagaimana Sabda Nabi Muhammad S.A.W. yang artinya:

Anak dilahirkan dalam keadaan suci sampai lisannya mengucapkan kehendak dirinya maka tergantung ayahnya, anak menjadi yahudi, nasrani atau majusi( H.R. Al-Aswad bin Surai).

Disamping orang tua membimbing dan memberi contoh, orang tua mengajak dialog mengenai hikmah berbusana sesuai dengan jenis kelaminnya. Hikmah berbusana sesuai jenis kelaminnya antara lain agar ruhnya tidak berubah menjadi lawan janis, misalnya anak perempuan yang selalu diberi pakaian laki-laki maka ruh anak tersebut yang menonjol maskulinnya dan begitu sebaliknya.

Karena keterbatasan kemampuan (intelek, waktu dan dana) orang tua maka mereka mengirimkan anaknya untuk diasuh disekolah, Tarbiatul Athfal atau Taman Kanak-Kanak agar sikap anak berbusana sesuai jenis kelaminnya berkembang atau berkisinambungan.

Tidak semua anak asuh di T A./ T.K. berasal dari keluarga yang sama, ada sebagaiananak asuh berasal dari orang tua yang mengetrapkan pola asuh dialogis dan sebagaian yang lain ada yang mengetrapkan pola asuh permisif. Pola asuh permisif yaitu pola asuh dimana orang tua membiarkan anak diasuh oleh masyarakat atau media massa yang ada, sambil berharap suatu saat akan terjadi keajaiban yang datang untuk menyulap anakanak mereka menjadi shaleh dan shalihah.

Berdasarkan perbedaan latar belakang keluarga anak asuh di T.A/ T.K maka dalam pembentukan sikap 
berbusana sesuai jenis kelaminnya dengan met ode individualisasi. Metode Individualisasi adalah metode pendidikan yang menekankan penyesuaian pengajaran kepada perbedaan-perbedaan individual murid. Jadi metode individualisasi adalah metode pendidikan yang menekankan penyesuaian pengajaran kepada perbedaan-perbedaan individual murid.

Domain pembentukan sikap anak untuk ranah berbusana sesuai jenis kelaminnya tidak hanya pada kognitif, afektif tetapi juga motor skill (Ahmad Tafsir:104). Motor skill dalam pendidikan Islam ada yang fisik dan ada yang psikiskill fisik misalnya Wudhu, berbusana sesuai jenis kelaminya. Pendidikan dalam ranah skill tersebut memerlukan metode individualisasi yaitu face to face agar guru dapat membimbing, memberi contoh, dan ikut serta menyelesaikan masalah.

Masalah yang dapat dirumaskan adalah 1. Sejauh mana pengaruh pola dialogis terhadap sikap anak berbusana sesuai jenis kelaminnya; 2. Sejauh mana pengaruh metode individualisasi terhadap sikap anak berbusana sesuai jenis kelaminnya; 3. Apa ada pengaruh pola asuh dialogis dan metode individualisasi terhadap sikap anak berbusana sesuai jenis kelaminnya.

\section{Pembahasan}

1. Konsepsi

Pola Asuh Orang Tua adalah pola perilaku yang diterapkan pada anak yang relatif, konsisten dari waktu ke waktu yang dapat dirasakan oleh anak baik dari segi positif maupun negatif. 
Pola asuh ada empat yaitu:

a) Pola asuh Demokratis. Pola asuh demokratis adalah pola asuh yang memperioritaskan kepentingagu anak, akan tetapi tidak ragu-ragu mengendalikan mereka. Ciri pola asuh ini pada orang tua bahwa orang tua bersikap rasional, realistis terhadap kemampuan anak, memberikan kebebasan kepada anak untuk memilih dan melakukan suatu tindakan, pendekatannya kepada anak bersifat hangat. Ciri pola asuh ini pada anak adalah bahwa anak mampu mandiri, mengontrol diri, mempunyai hubungan baik dengan teman, mampu menghadapi stres, minat terhadap hal-hal yang baru, kooperatif pada orang-orang lain.

b) Pola asuh otoriter. Pola asuh otoriter adalah pola asuh dimana orang tua telah menetapkan standar mutlak harus dituruti, biasanya dibarengi ancaman-ancaman. Ciri pola asuh ini pada orang tua bahwa orang tua bersikap cenderung memaksa, memerintah, menghukum., tidak mengenal kompromi (komunikasi satu arah,dari orang tua ke anak tidak seutbaliknya), tidak memerlukan pendapat anak. Ciri pola asuh ini pada anak bahw anak berkarakter penakut, pendiam, tertutup, tidak berinisiatif, gemar menentang, suka melanggar 
norma,berkepribadian lemah, cemas dan menarik diri.

c) Pola Asuh Permisif. Pola asuh Permisif adalah pola asuh dimana orang tua memberikan pengawasan yang sangat longgar, memberikan kesempatan pada anak tanpa pengawasan yang cukup darinya. Ciri pola asuh pada orang tua adalah bahwa orang tua tidak mau menegur atau memperingatkan anak apabila anak dalam bahaya, sangat sedikit bimbingan, bersifat hangat sehingga disenangi anak-anak. Ciri pola asuh ini pada anak adalah bahwa anak berkarakter impulsive, agresif, tidak patuh, manja, kurang mandiri, mau menang sendiri, kurang percaya diri, dan kurang matang secara sosial

d) Pola asuh Penelantar Pola asuh Penelantar. Pola asuh penelantar adalah pola asuh dimana orang tua tidak memberikan waktu dan dana yang cukup kepada anakanaknya. Ciri Pola asuh ini pada orang tua bahwa orang tua waktunya digunakan untuk bekerja dan biaya untuk anaknya dihemathemat, Ciri pola asuh ini pada anak adalah bahwa anak berkarakter moody, impusif, agresif, kurang bertanggung jawab, tidak mau mengalah, Self Esteem nya rendah, sering bolos, dan bermasalah dengan teman (Ira Pretanto:2006). 
Menurut Umu Dini (2004), tradisi pengasuhan anak ada tiga macam pola asuh yang digunakan dalam masyarakat yaitu:

a) Pola asuh Koersif. Pola asuh koersif adalah pola asuh dimana orang tua hanya mengenal Pujian dan Hukuman dalam interaksi dengan anak. Pujian akan diberikan kepada anak jika anak melakukan sesuai dengan keinginan orang tua. Sedangkan hukuman diberikan manakala anak tidak melakukan sesuai dengan keinginan orang tua. Akibat pola asuh ini pada anak maka anak berkarakter mencari perhatian, unjuk kekuasaan, pembalasan dan penarikan diri. b) Pola asuh Permisif. Pola asuh Permisif adalah pola asuh dimana orang tua memberi kebebasan kepada anaknya dengan harapan nanti mereka tahu sendiri tentang perbuatan mana yang boleh dan mana yang tidak atau orang tua tidak tahu mana yang lebih baik untuk anaknya. Akibat pola asuh ini pada anak, maka anak terjebak pada gaya hidup yang serba boleh dan sesuai persis tepat dengan pola yang berlaku pada masyarakat tempat dia dibesarkan. Di satu sisi orang tua akan selalu menanggung semua akibat perilaku anaknya tanpa mereka sendiri menyadari hal ini. 
c) Pola asuh dialogis. Pola asuh Dialogis adalah pola asuh dimana orang tua dalam mengasuh anaknya sesuai bimbingan Allah yaitu anak diarahkan sesuai dengan tujuan Allah menciptakan manusia dengan cara anak diberi pemahaman, diberi contoh, diajak berdialog jika anak belum faham tentang peraturan peraturan Allah dalam segala aspek kehidupan. Akibat dari pola asuh ini pada anak adalah anak merasa hidupnya penuh arti dan jika ada masalah mereka merujuk pada orang tua untuk menyelesaikan masalah tersebut.

Konsepsi pola asuh dalam penulisan ini menggunakan konsep pola asuh dialogis karena hal ini sesuai dengan pola asuh Islam sebagaimana Firman Allah dalam Surat An-Nahl ayat 125:Artinya:

Serulah (manusia) kepada jalan Tuhan-mu dengan hikmah dan pelajaran yang baik dan bantahlah mereka dengan cara yang baik. Sesungguhnya Tuhanmu Dialah yang lebih mengetahui tentang siapa yang tersesat dari jalan-Nya dan Dialah yang lebih mengetahui orang-orang yang mendapat petunjuk.

Ayat tersebut diatas menjelaskan bahwa seseorang dlperintahkan untuk mengasuh, membimbing, anak mengenai hal yang baik yang sesuai dengan tingkat kemampuan kognitif orang yang dibimbing, memberi contoh dan mengajak dialog tentang hal-hal yang perlu adanya dialog. Firman Allah dalam Surat An-Nisa'ayat 9 Artinya:

Dan hendaklah takut kepada Allah orang-orang yang seandainya meninggalkan 
dibelakang mereka anak-anak yang lemah, yang mereka khawatir terhadap (kesejahteraan) mereka. Oleh sebab itu hendaklah mereka bertakwa kepada Allah dan hendaklah mereka mengucapkan perkataan yang benar.

Ayat tersebut diatas menjelaskan bahwa anak tidak boleh ditinggal dalam keadaan lemah pisik dan psikisnya. Lemah Psikisnya antara lain anak tidak mengenal jenis kelaminnya maka mereka akan bersikap berbusana tidak sesuai dengan jenis kelaminnya.

Disamping alasan yang tersebut diatas, karena pola asuh dialogis dimana orang tua mempunyai konsep Ilahiyah dalam mengasuh anaknya yaitu sesuai dengan tujuan manusia diciptakan di bumi sebagai kholifah fil'ard agar anak tahu jenis kelamin sejak lahir sehingga mereka bersikap berbusana sesuai jenis kelaminnya. Penulis tidak memilih konsepsi pola asuh demokrasi walaupun berakibat baik pada anak karena pola asuh demokrasi dimana orang tua tidak mempunyai konsep Ilahiyah dalam mengasuh anaknya kalaupun ada konsepnya yaitu konsep yang disepakati masyarakat.

Lawan pola asuh dialogis adalah pola asuh permisif yaitu pola asuh dimana orang tua memberikan kebebasan untuk memilih apa yang disukai anak apakah anak mau berbusana sesuai jenis kelaminnya atau tidak.

Konsepsi pola asuh dialogis tidak dilawankan dengan pola asuh otoriter karena dalam pola 
asuh dialogis ada hal-hal dimana

anak tidak boleh memilih, contoh

anak perempuan ketika sholat

wajib menutup aurotnya atau

memakai mukena.

a. Pola Asuh Dialogis. Pola asuh dialogis menurut etimologi adalah pola berarti sistem, asuh berarti

membimbing(membantu,

melatih dan sebagainya)

supaya anak dapat berdiri

sendiri, dialogis berarti

bersifat komunikatif dan

terbuka. Jadi pola asuh

dialogis artinya pemimpin,

pembimbing yang komunikatif

dan terbuka atau orang yang

melakukan

tugas

membimbing, memimpin atau

mengelola yang bersifat

komunikatif dan terbuka.

Menurut terminologi pola asuh dialogis adalah suatu sistem atau pendidikan yang bersifat terbuka dan komunikatif yang dilakukan oleh seseorang kepada orang lain.

Menurut Ahmad Tafsir pola asuh dialogis adalah: Penambahan pengetahuan, Pembinaan Ketrampilan, Memberikan contoh atau teladan, Membiasakan(tentunya yang baik), Menegakan Disiplin; Memberikan Motivasi atau dorongan; Memberikan hadiah terutama psikologis; Menghukum (mungkin dalam kedisiplinan);Menciptakan suasana yang berpengaruh bagi pertumbuhan positif.

Menurut Amir Ahmad Sulaiman pola asuh dialogis yang terkait dengan berbusana 
sesuai jenis kelaminnya sebagi berikut: Membimbing (mengajarinya); Mengamati; Mengingatkan; Menjawab pertanyaan dengan jawaban yang sesuai usianya.

Jadi pola asuh dialogis dalam berbusana sesuai jenis kelaminnya dapat dilakukan sebagai berikut: Penambahan pengetahuan, Pembinaan Ketrampilan, Memberikan contoh atau teladan, Membiasakan (tentunya yang baik), Menegakan Disiplin; Memberikan Motivasi atau dorongan; Memberikan hadiah terutama psikologis; Menghukum (mungkin dalam kedisiplinan); Menciptakan suasana yang berpengaruh bagi pertumbuhan positif; Menjawab pertanyaan anak dengan jawaban yang sesuai usianya.

b. Metode Individualisasi. Metode Individualisasi menurut etimologi metode adalah cara yang tersusun dan teratur, untuk mencapai tujuan dalam hal pengetahuan. Individualisasi metode pendidikan yang menekankan penyesuaian pengajaran kepada perbedaan-perbedaan individual murid. Jadi metode individualisasi adalah metode pendidikan yang menekankan penyesuaian pengajaran kepada perbedaan-perbedaan individual murid.

Penerapan metode induvidualisasi adalah seorang guru memelihara suasana belajar yang kondusif. Guru memberi nasehat-nasehat 


$$
\begin{aligned}
& \text { terhadap kegiatan yang } \\
& \text { dilakukan anak, menjawab } \\
& \text { pertanyaan-pertanyaan dan } \\
& \text { memimpin kegiatan bersama- } \\
& \text { sama dengan anak-anak dalam } \\
& \text { hal-hal yang mereka } \\
& \text { inginkan. Dengan metode ini } \\
& \text { diharapkan semua anak } \\
& \text { mencapai keberhasilan belajar } \\
& \text { yang sama walaupun tidak } \\
& \text { dapat dipungkiri bahwa anak } \\
& \text { yang cerdas akan lebih cepat } \\
& \text { menyelesaikan tugasnya } \\
& \text { dibandingkan anak yang } \\
& \text { lemah. }
\end{aligned}
$$

Metode individualisasi ini dapat diterapkan pada semua materi pendidikan termasuk didalamnya bahan ajar pendidikan seks Islam.

Dimulai dengan pre tes untuk mengetahui hasil belajar pendidikan dari pola asuh tentang pendidikan seks Islam mengingat mereka dari latar belakang keluarga yang berbeda. Mereka diasuh disekolah dalam kondisi yang disesuaikan dengan jenis kelaminnya. Setelah terjadi proses belajar mengajar maka diadakan pos tes, untuk mengetahui tingkat keberhasilan semua anak secara individual.

c. Drill Project. Drill Project adalah salah satu metode individualisasi. Drill Project dalam pendidikan Islam adalah pengajaran ketrampilan. Pelajaran ketrampilan ada dua yaitu ketrampilan yang bersifat fisik misalnya sholat, menutup aurot, memakai pakaian sesuai jenis kelaminnya dan 
ketrampilan psikis misalnya berdo'a, hafalan-hafalan ayat al-Qur'an yang pendekpendek

Metode individualisasi dengan drill ini maka anak di pre tes berbusana sesuai jenis kelaminnya untuk mengetahui hasil pola asuh mengenai pendidikan seks Islam dari rumah. Jika sudah sesuai maka dikuatkan di sekolah bila belum sesuai maka ditambah pembiasaan.

d. Pendidikan Seks Islam. Pendidikan Seks Islam adalah upaya pengajaran, penyadaran, penerangan tentang masalahmasalah seksual yang diberikan kepada anak sejak ia mengerti masalah-masalah yang berkenaan dengan seks, naluri, dan perkawinan.
Dengan begitu. Jika anak telah dewasa, ia akan dapat mengetahui masalah-masalah yang diharamkan dan yang dihalalkan, bahkan mampu menerapkan perilaku Islami dan tidak akan memenuhi naluri seksualnya dengan caracara yang tidak Islami( Zulia Ilmawati, 2004).

Orang tua, Pendidik di Sekolah, Pengelola Negara sebaagai pihak yang bertanggung jawab dalam pendidikan seks. Diantara ketiganya yang paling pertama dan utama yang memberikan pendidikan seks kepada anak adalah orang tua. Oleh karena itu orang tua yang beragama Islam mempelajari pendidikan seks menurut Islam. Sedang orang tua yang tidak beragama 
Islam tidak ada dosa

kewajibannya yang telah mempelajari pendidikan seks ditentukan oleh Allah sesuai menurut Islam. dengan jenis kelaminnya, 3).

Adapun

Pokok

Pendidikan Seks Islam adalah

1). Menanamkan rasa malu

pada anak.Rasa malu ditanamkankan sejak dini yaitu dibiasakan memakai busana muslimah dan jangan dibiasakan telanjang dimuka orang saat keluar dari kamar mandi, berganti pakaian dan sebagainya, 2). Menanamkan jiwa maskulinitas pada anak laki-laki dan jiwa feminimitas pada anak perempuan. Secara fisik dan psikis anak laki-laki sangat berbeda dengan anak perempuan hal ini telah diciptakan sedemikian rupa oleh Allah. Masing-masing mereka mempunyai hak dan
Memisahkan tempat tidur mereka. Usia anak 7tahun sudah dipisahkan tempat tidurnya dengan saudaranya yng berbeds jenis kelamin, 4).Mengenalkan tiga waktu berkunjung. Jika anak mau berkunjung ke kamar orang tua harus mengetuk pintu kamar lebih dahulu karena saat-saat itu ada kemungkinan aurot orang dewasa terbuka (Al-Ahzab ayat 3), 5). Mendidik menjaga kebersihan alat kelamin. Anak dibiasakan mengeluarkan hadas kecil dan besar ditempatnya dan dibiasakan membersihkan alat kelamjnnya sesudah buang hadas kecil dan besar sehingga 
nantinya anak akan terbiasa

menjaga kebersihan sesuai

peraturan Islam, 6).

Mengenalkan mahramnya.

Anak dijelaskan perempuan

mana saja yang boleh dinikahi

dan perempuan mana sajayang

tidak boleh dinikahi (An-Nisa;

ayat 22-23), 7). Mendidik

anak agar selalu menjaga

pandangan mata. Dijauhkan

anak dari gambar, foto, film

dan bacaan-bacaan pornografi

dan porno aksi, 8). Mendidik

anak agar tidak melakukan

ikhtilat. Jangan dibiasakan

anak diajak ketempat-tempat

yang bercampur baur antara

laki-laki dan perempuan

secara bebas, 9). Mendidik

anak agar tidak melakukan

khalwat. Jangan membiasakan

anak bermain hanya berdua dengan teman yang berbeda

jenis kelamjn ditempat yang

sepi, 10). Mendidik etika

berhias. Dibiasakan jika

berhias agar terlihat menawan

tidak diniatkan untuk menarik

perhatian lawan jenis, 11).

Ihtilam dan haid. Anaklaki-

laki diberi penjelasan tentang

ihtilam sebagai tanda baligh

bagi anak laki-laki, dan anak

perempuan diberi penjelasan

tentang haid sebagai tand

baligh bagi anak perempuan.

Menurut Jamaal 'Abdur

Rahman (2000) Pokok-pokok

Pendidikan seks adalah: 1).

Sejak janin dalam kandungan

yaitu dengan dibacakan Surat

Maryam dan Surat Yusuf,

karena janin dalam kandungan

pendengarannya sudah

berfungsi (Surat Al-A'rof ayat 
172), 2). Aqiqoh yaitu anak setelah lahir disembelihkan dua ekor kambing untuk anak laki-laki dan seekor kambing untuk anak perempuan, 3). Pembiasaan berbusana sesuai jenis kelaminnya. Anak sejak usia tiga bulan dibiasakan memakai pakaian sesuai jenis kelaminnya, 4). Pembiasaan berpisah tempat tidur dengan orang tua. Anak usia dua tahun dipisahkan tempat tidurnya dari orang tuanya agar tidak ada memori pada anak tentang pelaksanaan hak dan kewajiban, walau halal bagi orang tuanya, 5). Pembiasaan berpisa tempat tidurnya dengan saudara yang berbeda jenis kelaminnya. Anak yang sudah baligh maka dibiasakan berpisah tempat tidurnya. Anak usia sekian sudah menyadari adanya perbedaan dengan saudaranya yang berbeda jenis kelamin, 6). Pembiasaan anak laki-laki tidak berbaur dengan anak perempuanyang bukan mahram dengan bebas atau tidak pembiasaan anak lakilaki dan anak perempuan berduaan di tempat sepi baik mahram maupun bukan, 7). Pembimbingan berhias. Anak perempuan boleh berhias agar terlihat menawan tetapi tidak untuk menarik perhatian lawan jenis, 8). Pembimbingan tentang ihtilam dan haid. Orang tua harus setiap saat siap untuk diajak dialog tentang ihtilam oleh anak lakilakinya atau tentang haid oleh anak perempuannya. 
Pokok-pokok Pendidikan

seks untuk anak usia

PraTaman Kanak- Kanak dan

usia Taman Kanak-Kanak

sebagai berikut: 1).

Pendidikan seks Pra T.K:

a).Sejak janin dalam

kandungan yaitu dengan

dibacakan Surat Maryam dan

Surat Yusuf, karena janin

dalam

kandungan

pendengarannya

sudah

berfungsi (Surat ayat 172), b).

Aqiqoh yaitu anak setelah

lahir disembelihkan dua ekor

kambing untuk anak laki-laki

dan seekor kambing untuk

anak perempuan, c).

Pembiasaan berbusana sesuai

jenis kelaminnya. Anak sejak

usia tiga bulan dibiasakan

memakai pakaian sesuai jenis

kelaminnya, d). Pembiasaan berpisah tempat tidur dengan

orang tua. Anak usia dua

tahun dipisahkan tempat

tidurnya dari orang tuanya

agar tidak ada memori pada

anak tentang pelaksanaan hak

dan kewajiban, walau halal

bagi orang tuanya, e).

Pembiasaan berpisah tempat

tidurnya dengan saudara yang

berbeda jenis kelaminnya.

Anak yang sudah baligh maka

dibiasakan berpisah tempat

tidurnya. Anak usia sekian

sudah menyadari adanya

perbedaan dengan saudaranya

yang berbeda jenis kelamin,

2). Pendidikan seks di Taman

Kanak-Kanak: a). Pembiasaan

anak laki-laki tidak berbaur

dengan anak perempuanyang

bukan mahram dengan bebas

atau tidak pembiasaan anak 
laki-laki dan anak perempuan berduaan di tempat sepi baik mahram maupun bukan, b). Pembimbingan berhias. Anak perempuan boleh berhias agar terlihat menawan tetapi tidak untuk menarik perhatian lawan jenis, c). Pembimbingan tentang ihtilam dan haid. Orang tua harus setiap saat siap untuk diajak dialog tentang ihtilam oleh anak lakilakinya atau tentang haid oleh anak perempuannya.

e. Sikap Berbusana sesuai jenis kelaminnya. Sikap adalah bentuk evaluasi atau reaksi perasaan. Sikap seseorang terhadap obyek adalah perasaan mendukung (memihak) atau perasaan tidak mendukung. Dapat juga sikap diartikan sebagai kesiapan untuk bereaksi terhadap sesuatu obyek dengan caracara tertentu. Atau sebagai suatu kecenderungan potensial untuk bereaksi apabila individu dihadapkan pada stimulus yang menghendaki ada respon. Atau Sikap diartikan sebagai konstelasi komponen kognitif, afektif, dan konatif, yang beraksi dalam memahami, merasakan dan berprilaku terhadap suatu obyek. Jadi sikap adalah suatu respon evaluatif dalam diri individu, yang memberi kesimpulan nilai terhadap stimulus dalam bentuk baik atau buruk, positif atau negatif, menyenangkan atau tidak menyenangkan, suka atau tidak suka, yang dikemudian mengkristal 


\begin{tabular}{|c|c|}
\hline sebagai potensi reaksi & ketiganya \\
\hline terhadap & konsisiten dan \\
\hline (Syaifuddin Azwar:1988). & ketiganya mengarah ke obyek \\
\hline Adapun struktur sikap & sikap secara seragam. \\
\hline bahwa sikap terdiri atas tiga & Konsisitensi \\
\hline komponen yang & kepercayaan \\
\hline menunjang, yaitu komponen & komponen, perasaan sebagai \\
\hline kognitif, komponen afektif, & komponen afektif dan perilaku \\
\hline komponen konatif. Komponen & sebagai komponen \\
\hline kognatif berupa apa yang & dijadikan landasan \\
\hline dipercayai subyek pemilik & penyimpulan \\
\hline sikap, komponen & melaluiobservasi \\
\hline merupakan perasaan yang & (pernyataan/perihal) \\
\hline menyangkut aspek emosional & dicerminkan oleh \\
\hline dan komponen & terhadap skala sikap. \\
\hline merupakan & Selanjutnya sikap dapat \\
\hline kecenderungan & dibentuk, \\
\hline tertentu dengan sikap yang & Pengalamn pribadi: Pengaruh \\
\hline dimiliki oleh subyek. & orang lain yang \\
\hline Komponen-komponen & penting; Pengaruh lembaga \\
\hline sikap jika dihadapkan pada & pendidikan \\
\hline
\end{tabular}

komponen sikap akan interaksi 
f. Berbusana sesuai jenis kelaminnya. ecara fisik maupun psikis, laki-laki dan permpuan mempunyai perbedaan mendasar. Perbedaan tersebut telah diciptakan sedemikian oleh Allah. Adanya perbedaan ini bukan untuk saling merendahkan, namun sematamata karena fungsi yang berbeda dalam berperan.

Mengingat perbedaan tersebut, Islam telah memberikan tuntunan agar masing-masing fithrah yang telah ada tetap terjaga. Islam menghendaki agar laki-laki memiliki kepribadian yang maskulin, dan telah ada tetap terjaga. Islam menghendaki agar laki-laki memiliki kepribadian maskulin, dan perempuan memiliki kepribadian feminim. Islam tidak menghendaki wanita nenyerupai laki-laki begitu juga sebaliknya. Untuk itu, harus dibiasakan dari kecil anak-anak berpakaian sesuai jenis kelaminnya dan diperlakukan sesuai dengan jenis kelaminnya. Ibn Abbas r.a. berkata:

Rasululloh S.A.W., melaknat laki-laki yang berlagak wanita dan wanita yang berlagak meniru lakilaki.(HR Al-Bukhari)

Rasulullah S.A.W. bersabda:

Telah diharamkan mengenakan kain sutera dan emas bagi kaum lakilaki umatk dan dihalalkan bagi kaum wanitanya(HR At-Turmidi)

\section{Hasil Penelitian}

Hasil penelitian tentang Pola Asuh Dialogis Dan Metode 
Individualisasi Dalam Pendidikan

Seks Islam Pada Pendidikan Agama Islam Terhadap Sikap Anak

Berbusana Sesuai Jenis

Kelaminnyanya yang jenis

penelitiannya Ex-post-facto dan

datanya diolah dengan ANAVA menunjukan bahwa Pola asuh dialogis dalam pendidikan seks Islam berpengaruh positif pada sikap anak berbusana sesuai jenis kelaminnya $(\mathrm{Fo}>\mathrm{Ft}$ atau 38,55>4,11). Hal ini sesuai dengan pendapat Ahmad Tafsir (1995) bahwa untuk pembinaan sikap anak berbusana sesuai jenis kelaminnya yang dilakukan orang tua dengan membimbing, membina, mengingatkan, memberi contoh, mengajak dialog anaknya akan berbeda dengan orang tua yang tidak pernah membina sikap anaknya berbusana sesuai jenis kelaminnya di rumah, mereka menyerahkan pembinaan hal tersebut kepada sekolah padahal waktu anak di sekolah lebih sedikit bila dibandingkan waktu anak di rumah.

Selanjutnya dari hasil penelitian diatas menunjukan bahwa metode individualisasi berpengaruh positif terhadap sikap anak berbusana sesuai jenis kelaminnya $(\mathrm{Fo}>\mathrm{Ft}$ atau $33,33>4,11)$. Hal ini sesuai pendapat Ahmad Tafsir bahwa sekolah harus memperhatikan tiap individu anak asuh dalam membina anak tetap berbusana sesuai jenis kelaminnya. Pembinaan sikap anak berbusana sesuai jenis kelaminnya merupakan ketrampilan maka perlu adanya metode individualisasi, agar anak asuh memiliki sikap yang sama untuk berbusana sesuai jenis kelaminnya. 
Dari penelitian diatas, selain menunjukan dua hal tersebut diatas, juga menunjukan bahwa pola asuh dialogis dan metode individualisasi jika diterapkan bersamaan, berpengaruh positif terhadap sikap anak berbusana sesuai jenis kelaminnya $(\mathrm{Fo}>\mathrm{Ft}$ atau $6,32>4,11)$. Hal ini sesuai pendapat Ahmad Tafsir bahwa harus ada kerja sama antara sekolah dan orang tua dalam membina anak berbusana sesuai jenis kelaminnya.

Dari perumusan masalah, landasan teori, dan hasil penelitian dapat disimpulkan bahwa:

1. Pola Asuh Dialogis sangat berpengaruh dalam pembinaan karakter anak untuk berbusanabsesuai jenis kelaminnya.

2. Metode Individualisasi adalah metode yang baik diterapkan dalam pembinaan ketrampilan (berbusana sesuai jenis kelaminnya) mengingat anak asuh berasal dari keluarga yang berbeda dalam mengetrapkan pola asuh.

3. Pola Asuh Dialogis dan Metode Individualisasi yang diterapkan secara bersamaan atau berkesinambungan akan menghasilkan pencapaian yang memuaskan terutama dalam hal pembinaan sikap anak berbusana sesuai jenis kelaminnya. Hal ini sebagai bukti adanya kesatuan misi dan visi antara orang tua dan guru disekolah.

Berdasarkan simpulan hasil penelitian tersebut, maka peneliti memberikan saran sebagai berikut: Pembinaan anak dalam segala aspek kehidupan hendaklah antara orang tua, guru, dan pengelola negara wajib 
satu visi dan satu misi agar negara ini

memiliki generasi penerus yang

iman, taqwa, berwawasan luas,

cerdas, kreatif. dan penuh inovasi

sehingga mempercepat negara ini

menjadi negara yang baldatun

thoyibatun wa robbun ghofur.

\section{Daftar Pustaka}

Abdur Rahman, Jamaal,2005,

Tahapan Mendidik Anak

Teladan Rasulullah, cetakan

1, Bandung: Irsyad baitus

Salam

Agustian, Ary Ginanjar, 2006,

Emosional Spiritual Quatient, cetakan 27, Jakarta: Arga

Ahmad, Al Hasyim,1993, Syarah

Mukhtarul Ahaadits, cetakan

1, Bandung: Sinar Baru.

Ali Had, Al Haq, 1986, Mengasuh Anak menurut Ajaran Islam, Jakarta: UNICEF Indonesia

Bahrul, Khair Amal, Pendidikan Anak Usia Dini, http://www.waspada.co.id/ser ba serbi/pendidikan artikel. Php artikel id 67766

Crow, Lester D, Allice Crow, Z. Ksijan, Psikologi Pendidikan, Buku 1, Cetakan 1, Surabaya: Bina Ilmu

Daryanto, 1998, Kamus Lengkap Bahasa Indonesia, cetakan 1, Surabaya: Apollo.

Departeman Agama Republik Indonesia, 1998, Al-Qur'an
Dan Terjemahannya, Juz 1Juz 30, Surabaya: Mahkota.

Departemen Pendidikan dan kebudayaan, 1995, Kamus BesarBahasa Indonesia, Jakarta: Balai Pustaka.

Hasbullah, 1999, Dasar-Dasar Pendidikan, Cetakan 1, Jakarta:Raja Grafinda Persada

Hurlock, Elizabet B, 1980, Psikologi Perkembangan Anak,Suatu Pendekatan Sepanjang rentang kehidupan,ES.D, Alih Bahasa, istidayanti, Sudjarwo, jakarta: Erlanga.

Jalaludin, 1977, Psikologi Agama, Cetakan 1l, Jakarta: Raja Grafindo persada

Jacinta, F. Rini, 2002, Konsep Diri, http://www.e-

psikologi.com/jenewa/160502 htm

John, Gotman, Joan De Claire, 2003, Kiat-Kiat Membesarkan Anak Yang Memiliki Kecerdasan Emosional, Alih Bahasa Hermaya, Cetakan 6, Jakarta PT Gramedia.

Jusuf, Amir Faisal, 1995, Reoreintasi Pendidikan Islam, Cetakan 1, Surabaya: Bina Ilmu

Malawi, Ibadullah, 2007, Statistik Lanjut, Madiun: F.I.P.IKIP PGRI.

Malik B Badri, 1986, Dilema Psikologi Muslim, terjemahan SitiZainla Hurfiati, Jakarta: Pustaka Firdaus.

Monks, F. J, A. M. P. Knors, 2004, Psikologi Perkembangan Pengantar berbagai Perkembangannya, Cetakan 16, Yogyakarta: Gajah Mada Press. 
Mar'at, Sikap Manusia, Perubahan Dan Pengukurannya, Jakarta: Ghali Indonesia.

Marfuah Panji Astuti, 4Tipe Pola Asuh Orang Tua, hhtp://www.tabloit.nakita.co $\mathrm{m} /$ hasanah 06279-02htm

Muh.Nazir, Metode Penelitian, Cetakan 1, Jakarta: Galia Indonesia.

Moh. Shohib, 1998, Pola Asuh Orang Tua Dalam membantu Anak Mengembangkan Disiplin Diri, Cetakan 1, Jakarta: Reinika Cipta.

Petranto, Ira, Rasa Percaya Diri Anakadalah Pantulan Pola Asuh Orang Tuanya, http://dwpp.jenewa.,

Swisse.com/buletin/?,Cetakan 5

Sudjono, Nana, Ibrahim, 2001, Penelitian dan Penilaian Pendidikan, Cetakan 11, Bandung: Sinar Baru Al Gesnida.

Saifuddin Azwar, Sikap Manusia Teori dan Pengukurannya, Cetakan 1, Yogyakarta: Liberty

Suhardi, Metodologi Penelitian dan Prakteknya, Cetakan 1, Jakarta: Bumi Aksara.

Suharsini Arikunto,1993, DasarDasar Evaluasi Pendidikan, Cetakan 1, Jakarta: Bumi Aksara.

.Tafsir, Ahmad, 1999, Metodologi Pengajaran Agama Islam, cetakan IV, Bandung: Remaja Rosda Karya.

Ummu Dini, 2004, Tarbiyatul Aulad, hhtp://www pks. Anz.org/modulus,php?namil= news file $=$ artick sid $=$

Zulia Ilmawati, Pendidikan Seks Untuk Anak, hhtp://hizbut- tahrir.or.id/main.php?page=al waie\&id=204 